\title{
PENGEMBANGAN MODEL PROJECT BASED LEARNING TERHADAP MOTIVASI DAN AKTIVITAS BELAJAR SISWA
}

\author{
Nur Hidayah, Satrianawati \\ Program Studi Pendidikan Guru Sekolah Dasar FKIP UAD \\ Jalan Ki Ageng Pemanahan No. 19 Sorosutan Yogyakarta
}

\begin{abstract}
ABSTRAK
Penelitian ini merupakan jenis penelitian pengembangan pendidikan (educational research and development) dengan tujuan yang diharapkan adalah adanya produk dari penelitian yang dilakukan berupa pengembangan model project based learning pada pembelajaran matematika yang dapat digunakan oleh guru-guru yang mengajar di sekolah dasar inklusi. Sasaran penelitian pengembangan ini adalah meningkatnya aktivitas dan motivasi belajar matematika siswa di sekolah dasar inklusi. Hasil Penelitian menunjukkan langkah-langkah yang paling efektif dalam mengembangkan model project based adalah menganalisis kebutuhan, mendesain pengembangan, memproduksi/ mengembangkan model project based learning, melakukan evaluasi pengembangan, dan melakukan uji coba lapangan dan kualitas pengembangan model project based learning yang dikembangkan menurut penilaian ahli pengembangan model termasuk kriteria "sangat baik" dengan rerata skor 5, menurut ahli pembelajaran termasuk kriteria "baik" dengan rerata skor 4,3.
\end{abstract}

Kata Kunci: pengembangan model project based learning, pembelajaran, matematika, pendidikan inklusi, \& sekolah inklusi

\begin{abstract}
Inclusive education is a system of education that provides opportunities for all learners who have disabilities and have the potential of intelligence or a special talent to follow education and learning in the educational environment together with learners in general. In school, inclusive learning is done simultaneously and together, thus eliminating differences in determining attitudes toward students with various abilities. In the inclusive education system in inclusive schools, the project-based learning model is a learning model that successfully accommodates the learners' diversity to be able to get a fun learning process and can understand the need for self-development in children. Therefore, the implementation of project-based learning model in the perspective of inclusive education needs to be known by all observers of education so that the education quality can be improved.
\end{abstract}

Keywords: Inclusive Education, Project-based Learning. 


\section{Pendahuluan}

Proses pembelajaran merupakan sesuatu hal yang berkesinambungan dan berlangsung sepanjang hayat. Pembelajaran dengan hasil yang memuaskan, membutuhkan proses yang maksimal. Untuk melaksanakan proses yang maksimal seorang guru perlu merancang pembelajran yang dapat memfasilitasi tiga gaya belajar siswa. Gaya belajar siswa terdiri dari gaya belajar visual, auditori, dan kinestetik, sekalipun anak tersebut merupakan anak berkebutuhan khusus.

Tiga gaya belajar ini dimiliki oleh semua orang tidak hanya anakanak yang berkebutuhan khusus, terutama anak-anak yang disekolahkan di sekolah inklusi oleh orang tuanya. Dalam kehidupan sehari-hari, banyak anak-anak yang perlu diperhatikan, tidak hanya dari sikap anak yang membutuhkan perhatian. Ungkapan “caper" atau cari perhatian untuk anak bukan hal yang tabuh, melainkan menjadi hakikat anak-anak itu sendiri bahwa dalam masa kanak-kanak mereka membutuhkan perhatian yang serius dalam kegiatannya sehari-hari. Menjadi "caper" merupakan hal yang Pengembangan ... (Nur Hidayah) terjadi dalam kehidupan anak-anak, dan hal tersebut merupakan sesuatu yang normal. Gaya caper anak membuat anak melakukan beragam aktivitas yang memancing perhatian guru.

Tiga gaya belajar yang dimiliki anak memiliki kapasitas yang berbeda. Anak-anak yang berada di sekolah inklusi tentunya memiliki ketiga gaya belajar ini. Akan tetapi gaya belajar mereka yang pasti belum dapat diketahui dengan jelas oleh orang lain. Gaya belajar anak di sekolah perlu difasilitasi dengan baik. Terlebih lagi bagi anak-anak yang berada di sekolah inklusi tentunya perlu diperlakukan seperti kebanyakan anak-anak lainnya. Ini menunjukkan bahwa tindakan untuk anak inklusi harus diperhatikan oleh semua orang tidak hanya untuk sekolah inklusi.

Pembelajaran di sekolah inklusi tidak jauh berbeda dengan sekolahsekolah pada umumnya. Perbedaan mendasar di sekolah inklusi adalah banyak ditemukannya siswa yang memiliki kelebihan tertentu atau kekurangan tertentu. Sikap dalam melakukan aktivitas belajar juga berbeda. Sekolah inklusi juga mempelajari pelajaran matematika. Jadi, pembelajaran matematika di 
sekolah inklusi dilakukan agar anakanak di sekolah inklusi mampu bersaing dengan sekolah-sekolah lainnya. Akan tetapi, aktivitas belajar matematika siswa di sekolah inklusi menunjukkan bahwa proses pembelajaran dan perlakuan-perlakuan yang diberikan oleh guru-guru untuk anak-anak berkebutuhan khusus di sekolah inklusi belum menunjukkan aktivitas dan motivasi belajar yang baik. Ini dikarenakan pembelajaran hanya terjadi satu arah sehingga pembelajaran tidak efektif. Selain itu, gaya belajar anak yang belum diperhatikan dalam pembelajaran sehingga anak melakukan aktivitas di luar pembelajaran. Kurangnya perhatian siswa dalam belajar sehingga ketika guru memberikan beberapa pertanyaan dan hanya beberapa siswa yang menjawab. Kalaupun ada yang menjawab, cenderung ikut-ikutan temannya.

Banyaknya aktivitas siswa di luar dari aktivitas pembelajaran sehingga menimbulkan pembelajaran yang tidak efektif. Kurangnya motivasi belajar siswa juga terlihat dari kegiatan siswa yang kurang memperhatikan pelajaran, lebih banyak mengganggu teman sebangkunya, jikapun dipisahkan dari teman sebangku maka siswa tersebut mengganggu belajar teman lainnya. Sehingga yang terjadi di kelas guru menyampaikan materi dan siswa mendengarkan, diberikan pertanyaan oleh guru hanya beberapa siswa yang menjawab. Kalaupun ada yang menjawab, cenderung ikut-ikutan temannya. Hal ini menunjukkan bahwa masalah belajar terkait proses dan model pembelajaran yang diterapkan cukup memprihatinkan.

$$
\text { Pentingnya penelitian }
$$
pengembangan model project based learning mengupayakan bahwa siswa dijadikan menjadi tidak sedang belajar. Karena disesuaikan dengan kecenderungan siswa, bahwa siswa sekolah dasar $75 \%$ yang dilakukannya untuk bermain dan $25 \%$ waktunya digunakan untuk belajar. Berdasarkan hal tersebut, para peneliti tertarik untuk melakukan penelitian tentang bagaimana pengembangan model project based learning terhadap aktivitas dan motivasi belajar siswa kelas IV SD pada pembelajaran matematika di sekolah dasar inklusi?.

\section{Metode Penelitian}

Penelitian ini merupakan jenis penelitian dan pengembangan pendidikan (educational research end 
development) bertujuan untuk

memvalidasi

produk-produk

mengembangkan model project based

pendidikan.

Adapun model

learning dalam pembelajaran pengembangan dapat digambarkan

matematika untuk meningkatkan

aktivitas dan motivasi belajar siswa di sekolah dasar inklusi pada kompetensi dasar membentuk berbagai bangun datar. Borg \& Gall (2007: 589) menyatakan bahwa "research and development is an-industry-based development model in which the findings of research are used to design new products and procedures, which then are systematically field tested, evaluated, and refined until they meet specified criteria of effectiveness, quality, or similar standards". Maksudnya bahwa penelitian pengembangan merupakan sebuah mode usaha pengembangan untuk menemukan produk dengan desain baru yang terlebih dahulu melalui proses uji lapangan, evaluasi, dan revisi sebelum diproduksi secara masal. Lebih lanjut Borg \& Gall (2007: 772) menyatakan bahwa "education research and development $(\mathrm{R} \& \mathrm{D})$ is a process used to develop and validate educational products". Maksudnya bahwa penelitian pendidikan dan pengembangan adalah suatu proses untuk mengembangkan dan

sebagai berikut:

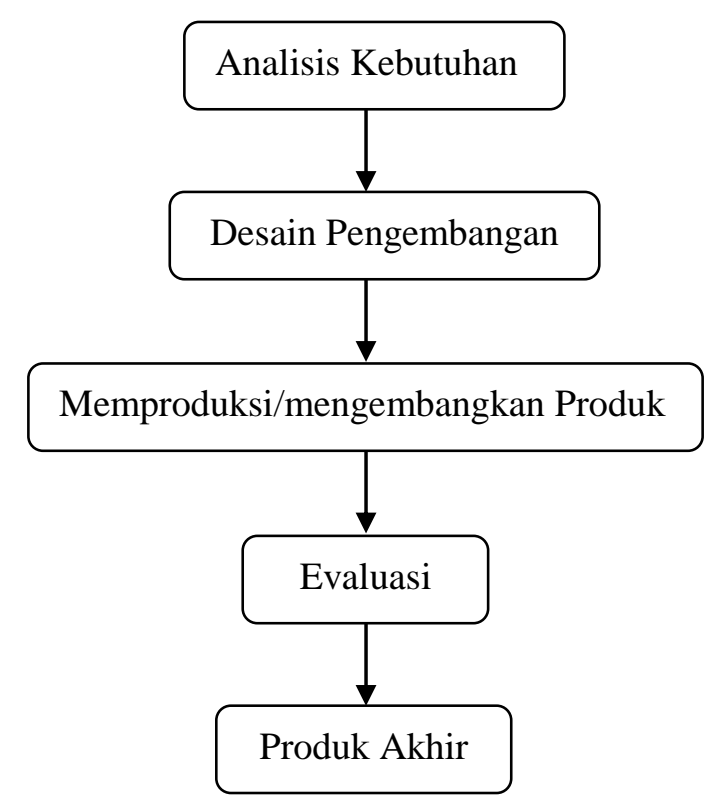

Gambar 1. Model Pengembangan Project Based Learning

Prosedur Pengembangan

Langkah-langkah

pengembangan atau prosedur pengembangan yang didapatkan dari model pengembangan Dick \& Carrey (Borg \& Gall 2007) adalah sebagai berikut:

1. Analisis kebutuhan. Tahap ini bertujuan untuk mendapatkan informasi yang relevan terkait dengan pengembangan model project based learning dalam pembelajaran matematika untuk meningkatkan aktivitas dan motivasi 
belajar siswa di sekolah dasar inklusi pada kompetensi dasar membentuk berbagai bangun datar dengan menggunakan papan berpaku atau media lainnya. Analisis ini meliputi analisis karakteristik siswa, studi pustaka dan observasi lapangan untuk menemukan permasalahan yang ada terkait aktivitas dan motivasi belajar siswa sekolah dasar inklusi.

2. Desain pengembangan. Setelah melakukan analisis karakteristik siswa, studi pustaka dan observasi lapangan, maka informasi yang telah terkumpul dijadikan acuan sebagai pengembangan model project based learning dalam pembelajaran matematika untuk meningkatkan aktivitas dan motivasi belajar siswa di sekolah dasar inklusi pada kompetensi dasar membentuk berbagai bangun datar dengan menggunakan papan berpaku atau media lainnya.

3. Memproduksi/mengembangkan model project based learning untuk digunakan di semua sekolah dasar inklusi. Tahap ini merupakan sebuah rangkaian proses produksi untuk menghasilkan rancangan pengembangan model project based learning dalam pembelajaran matematika untuk meningkatkan aktivitas dan motivasi belajar siswa di sekolah dasar inklusi pada kompetensi dasar membentuk berbagai bangun datar dengan menggunakan papan berpaku atau media lainnya.

4. Evaluasi. Tahap ini merupakan tahap evaluasi produk. Produk yang telah dikembangkan divalidasi oleh ahli yaitu ahli pembelajaran. Apabila ahli pembelajaran menyatakan bahwa produk yang telah dibuat sudah layak untuk diuji coba di lapangan, maka peneliti kemudian melanjutkan uji coba produk. Uji coba lapangan dilakukan di SD inklusi yaitu di Giwangan. Adapun tujuan akhir dari evaluasi ini adalah mendapatkan produk akhir yang siap diimplementasikan secara luas di masyarakat.

5. Produk akhir. Tahap ini merupakan tahap dimana produk yang telah diuji cobakan diproduksi dan disebarluaskan.

Uji Coba Produk

Uji coba dimaksudkan untuk memperoleh data secara lengkap yang dapat digunakan sebagai bahan revisi produk. Aspek yang divalidasi dalam 
tahap uji model pengembangan ini meliputi beberapa hal berikut ini:

a. Validasi ahli

Produk yang dikembangkan divalidasi oleh ahli pembelajaran sebelum diujicobakan kepada siswa. Validasi dari ahli berupa penilaian, komentar, dan saran perbaikan sangat diperlukan agar produk yang dikembangkan layak diterapkan dan sesuai dengan kebutuhan siswa sekolah dasar inklusi.

b. Desain Uji Coba, yaitu uji coba lapangan (field trial).

Hasil uji coba lapangan (field trial) pengembangan model project based learning kemudian diperbaiki dan disempurnakan sehingga produk akhir pembelajaran layak disebarluaskan kepada para guru di sekolah dasar inklusi untuk meningkatkan aktivitas dan motivasi belajar siswa pada kompetensi dasar membentuk berbagai bangun datar dengan menggunakan papan berpaku atau media lainnya.

c. Subjek Coba

Subjek ujicoba atau responden yang terlibat dalam penelitian ini adalah siswa sekolah dasar inklusi kelas IV dalam pembelajaran matematika pada kompetensi dasar membentuk berbagai bangun datar dengan menggunakan papan berpaku atau media lainnya.

Instrumen Pengumpulan Data Instrumen yang digunakan untuk mengumpulkan data pada penelitian ini berupa lembar validasi ahli dan anket untuk siswa. Lembar validasi digunakan untuk mengukur/mengevaluasi kelayakan produk yang dikembangkan. Lembar angket digunakan untuk mengukur kelayakan produk yang dikembangkan dari tahap identifikasi, pengembangan, dan evaluasi dan atau revisi oleh ahli pembelajaran dan oleh siswa. Data berupa komentar, saran perbaikan dan hasil pengamatan peneliti selama proses ujicoba dianalisis secara deskriptif dan disimpulkan sebagai masukan untuk memperbaiki atau merevisi produk yang telah dikembangkan. Langkah-langkah yang digunakan untuk menentukan kriteria kelayakan produk yang dikembangkan yaitu dengan mengkonvensi skor yang diperoleh menjadi data kuantitatif dengan menggunakan skoring yang dilihat pada tabel berikut: 
Tabel 1. Pedoman Skoring Data Interval Siswa

\begin{tabular}{|c|c|c|}
\hline Kriteria & Skor & Makna \\
\hline $\begin{array}{l}\text { Sangat } \\
\text { baik }\end{array}$ & 5 & $\begin{array}{l}100 \% \text { sesuai dengan } \\
\text { unsur-unsur yang ada } \\
\text { dalam } \\
\text { pertanyaan/pernyataan. }\end{array}$ \\
\hline Baik & 4 & $\begin{array}{l}80 \% \text { sesuai dengan } \\
\text { unsur-unsur yang ada } \\
\text { dalam } \\
\text { pertanyaan/pernyataan. }\end{array}$ \\
\hline Kurang & 3 & $\begin{array}{l}60 \% \text { sesuai dengan } \\
\text { unsur-unsur yang ada } \\
\text { dalam } \\
\text { pertanyaan/pernyataan. }\end{array}$ \\
\hline Cukup & 2 & $\begin{array}{l}40 \% \text { sesuai dengan } \\
\text { unsur-unsur yang ada } \\
\text { dalam } \\
\text { pertanyaan/pernyataan. }\end{array}$ \\
\hline $\begin{array}{l}\text { Sangat } \\
\text { kurang }\end{array}$ & 1 & $\begin{array}{l}20 \% \text { sesuai dengan } \\
\text { unsur-unsur yang ada } \\
\text { dalam } \\
\text { pertanyaan/pernyataan. }\end{array}$ \\
\hline
\end{tabular}

Angket yang diberikan terdiri atas lima pilihan untuk memberikan tanggapan tentang produk yang dikembangkan, yaitu sangat baik (5), baik (4), cukup (3), kurang (2), dan sangat kurang (1). Tanggapan siswa sangat baik pada butir pernyataan pernyataan, maka skor butir tersebut sebesar "5" demikian seterusnya. Skor yang diperoleh kemudian dikonversikan menjadi data kuantitatif. Kelayakan pengembangan model project based learning dalam pembelajaran matematika dapat meningkatkan aktivitas dan motivasi belajar siswa di sekolah dasar inklusi pada kompetensi dasar membentuk berbagai bangun datar dengan menggunakan papan berpaku atau media lainnya untuk aspek pembelajaran dari ahli pembelajaran, yang dinyatakan dengan angka berskala 1-5. Untuk mencari skor rata-rata (rerata skor) dalam memberikan penilaian terhadap produk yang telah dikembangkan digunakan rumus:

$$
x_{i}=\frac{\sum i}{N}
$$

Keterangan:

$x_{i}=$ Skor rata-rata

$\sum x_{i}=$ Jumlah Skor

$N=$ Jumlah Responden

Data proses pengembangan model project based learning dalam pembelajaran matematika untuk meningkatkan aktivitas dan motivasi belajar siswa di sekolah dasar inklusi pada kompetensi dasar membentuk berbagai bangun datar dengan menggunakan papan berpaku atau media lainnya berupa data deskriptif, dicermati, disusun, dan ditabulasi.. 
Tabel 2. Penghitungan Skor Untuk Produk (Widoyoko Eko Putro, 2009:238)

\begin{tabular}{clc}
\hline No. & $\begin{array}{c}\text { Rentang Skor }(i) \\
\text { kuantitatif }\end{array}$ & $\begin{array}{c}\text { Kriteria } \\
\text { Kualitatif }\end{array}$ \\
\hline $\mathbf{1}$ & $\mathrm{X}>\left(\bar{x}_{\mathrm{i}}+1,8 \mathrm{sb} i\right)$ & Sangat Baik \\
$\mathbf{2}$ & $\left(\bar{x}_{\mathrm{i}}+0,6 \mathrm{sb} i\right)<\mathrm{X} \leq$ & Baik \\
& $\left(\bar{x}_{\mathrm{i}}+1,8 \mathrm{sb} i\right)$ & \\
$\mathbf{3}$ & $\left(\bar{x}_{\mathrm{i}}-0,6 \mathrm{sb} i\right)<\mathrm{X} \leq$ & Cukup \\
& $\left(\bar{x}_{\mathrm{i}}+0,6 \mathrm{sb} i\right)$ & \\
$\mathbf{4}$ & $\left(\bar{x}_{\mathrm{i}}-1,8 \mathrm{sb} i\right)<\mathrm{X} \leq$ & Kurang \\
& $\left(\bar{x}_{\mathrm{i}}-0,6 \mathrm{sb} i\right)$ & \\
$\mathbf{5}$ & $\mathrm{X} \leq\left(\bar{x}_{\mathrm{i}}+1,8 \mathrm{sb} i\right)$ & $\begin{array}{l}\text { Sangat } \\
\end{array}$ \\
& & Kurang \\
\hline
\end{tabular}

\section{Keterangan:}

$\bar{x}_{\mathrm{i}}=$ rerata ideal $=\frac{1}{2}($ skor

maksimum ideal + skor minimum ideal)

$\mathrm{sb} i=$ rerata ideal $=\frac{1}{2}(\mathrm{skor}$

maksimum ideal - skor minimum ideal)

skor maksimum ideal $=\Sigma$ ( butir

penilaian $\mathrm{x}$ skor tertinggi)

skor minimum ideal $=\Sigma($ butir

penilaian $\mathrm{x}$ skor terendah)

$\mathrm{x}=$ skor empiris

Menganalisis kualitas produk pengembangan model project based learning dalam pembelajaran matematika untuk meningkatkan aktivitas dan motivasi belajar siswa di sekolah dasar inklusi pada kompetensi dasar membentuk berbagai bangun datar dengan menggunakan papan berpaku atau media lainnya. Produk yang dikembangkan memiliki kualitas yang baik jika minimal validitas yang dicapai adalah pada tingkat baik.

\section{Hasil Dan Pembahasan}

Hakikat pembelajaran matematika sangat meluas sehingga dibutuhkan pemahaman tentang matematika dalam kehidupan seharihari. Hal ini dijelaskan dalam buku the National Council of Teacher of Mathematics NCTM, (2000: 4) yaitu: (a) Mathematics for life, maksudnya dengan mengetahui matematika dapat memuaskan dan memberdayakan pribadi seseorang; (b) Mathematics as a part of cultural heritage, maksudnya bahwa matematika merupakan salah satu prestasi budaya dan intelektual terbesar manusia, dan warga negara harus mengembangkan apresiasi dan pemahamannya, termasuk aspek estetika dan bahkan rekreasi; (c) Mathematics for the workplace, maksudnya matematika diperlukan di tempat kerja maupun di bidang profesional lainnya mulai dari kesehatan hingga desain grafis; dan (d) Mathematics for the scientific and technical community, maksudnya semua karir 
memerlukan dasar pengetahuan matematika.

Joyce, Calhoun, \& Hopkins

(2009: 118) menyatakan bahwa dalam melakukan proses pembelajaran kita harus memberikan inspirasi. Tidak hanya sekedar rumus atau proses yang diikuti akan tetapi menjadi pembentuk lingkungan belajar yang mempersiapkan siswa mendapatkan pengalaman baru dalam pembelajaran. Adapun model project based learning yang akan dikembangkan dalam penelitian ini adalah mengacu pada pendapat Muresan (2014: 304) yang menyatakan bahwa "model pembelajaran yang berpusat pada siswa, memastikan pengembangan pengetahuan dan keterampilan pada bidang tertentu atau beberapa daerah, melalui tugas-tugas pekerjaan yang luas yang mempromosikan penyelidikan dan otentik demonstrasi berorientasi hasil pembelajaran. Olehnya itu, siswa diberikan tugas belajar untuk mengembangkan pengetahuan yang diperolehnya melalui kegiatan penyelidikan yang diamati dalam konteks kehidupan nyata.
Hârtescu (2014: 224) juga

mengatakan bahwa "menyelenggarakan belajar dalam proyek" dan melibatkan siswa dalam situasi otentik dimana siswa dapat mengeksplorasi dan memecahkan masalah pokok yang sangat kompleks dan relevan dengan praktek profesional yang telah dipersiapkan. Siswa bekerja secara mandiri, sesuai tujuan yang ditentukan, dan didorong untuk merencanakan tindakan mereka, membuat keputusan sendiri, dan bekerja bersama-sama untuk mendapatkan hasil yang diinginkan.

Oleh karena itu pengembangan model project based learning mempunyai tujuan yang sejalan dengan pendapat Santrock (2012: 33) bahwa "dalam pembelajaran berbasis proyek, murid-murid bekerja secara nyata, mengkaji masalah-masalah berarti dan menciptakan produk yang nyata". Lebih lanjut Boric (2007: 365) menyatakan bahwa belajar berbasis proyek adalah pendekatan pembelajaran yang mempromosikan motivasi intrinsik dengan mengorganisir instruksi di sekitar tugas-tugas yang paling mungkin 
untuk mendorong dan mendukung minat pelajar, usaha, dan ketekunan. Jadi melalui penerapan project based learning siswa akan memiliki motivasi untuk dapat menyelesaikan tugas dengan tekun karena siswa tertantang dalam memecahkan masalah yang berkaitan dengan kehidupannya sehari-hari.

Pickens, et al. (2012) juga menyatakan bahwa "project based learning adalah strategi belajar yang berpusat, berakar dalam paradigma andragogical, dan mengharuskan siswa untuk menanggapi pertanyaan atau tugas kompleks dengan menerapkan pengetahuan dan pemahaman tentang fenomena dalam pemecahan masalah atau kapasitas pengambilan keputusan yang berpuncak pada produk akhir yang relevan dengan pertanyaan atau masalah.

motivasi belajar merupakan suatu proses internal yang menggiatkan, menuntun, dan memelihara tingkah laku dalam jangka waktu yang lebih lama (Widoyoko, 2012: 233). Motivasi dapat diamati secara langsung tetapi dapat diinterpretasikan dalam tingkah lakunya, berupa rangsangan, dorongan, atau pembangkit tenaga munculnya tingkah laku tertentu (Uno, 2012: 1). Jadi, motivasi merupakan upaya menggerakkan jiwa dalam diri untuk mendorong tingkah laku atau aktivitas untuk melakukan kegiatan yang positif. Uno (2012: 3) mengatakan bahwa istilah motivasi berasal dari kata motif yang dapat diartikan sebagai kekuatan yang terdapat dalam diri individu, yang menyebabkan individu tersebut bertindak atau berbuat. Sedangkan Schunk (2010: 4) yang mendefinisikan bahwa motivasi merupakan suatu proses tidak dapat diobservasi secara langsung tetapi dilihat melalui tindakan. Sardiman (2011: 85) mengatakan terdapat tiga fungsi motivasi, yaitu mendorong siswa untuk berbuat, menentukan arah perbuatan, dan menyeleksi perbuatan. Jadi motivasi belajar juga dapat dilakukan dengan melakukan pengembangan model project based learning. 
Adapun prosedur pengembangan yang didapatkan dari model pengembangan Dick \& Carrey (Borg \& Gall 2007) yaitu menganalisis kebutuhan, mendesain pengembangan, memproduksi/mengembangkan materi, melakukan evaluasi produk, dan melakukan uji coba produk akhir sehingga dapat dilanjutkan dengan proses produksi dan disebarluaskan. Sednagkan langkah-langkah model Project based learning sesuai dengan $\mathrm{K}-13$, yaitu:

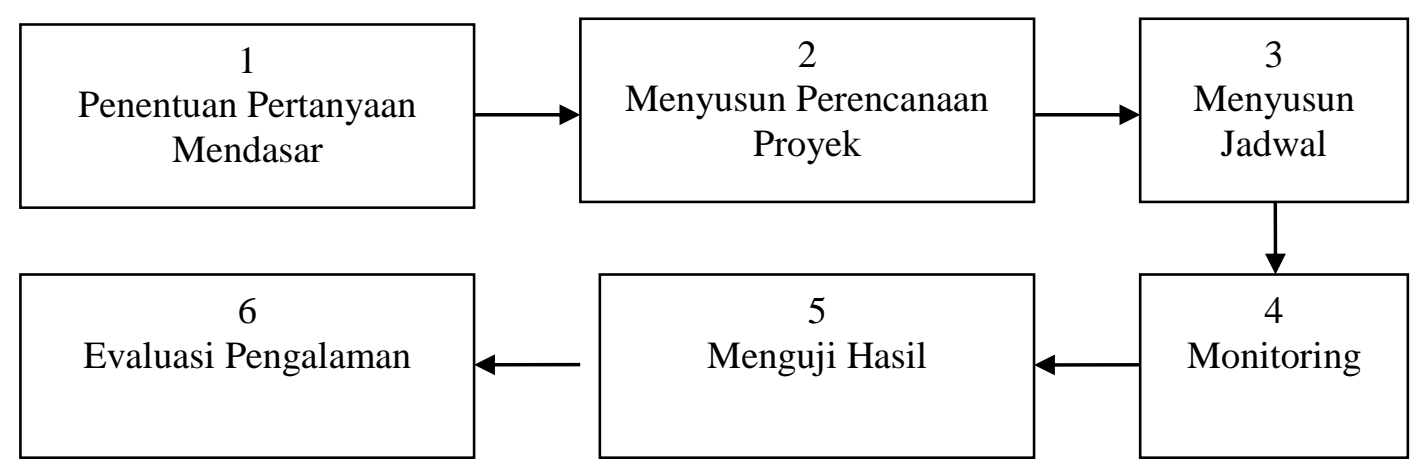

Gambar 2. Langkah-langkah project based learning menurut kurikulum 2013

Selanjutnya dari langkahlangkah 2013, juga didesain dari langkah yang dibuat oleh Bender (2012: 45-57) adalah sebagai berikut:

a) A project anchor maksudnya setiap usaha harus dibuat untuk menggambarkan jaringan untuk proyek-proyek project based learning yang akan membantu siswa menjadi tertarik dalam masalah yang akan diselesaikan.

b) A driving Question maksudnya ada pertanyaan mendasar yang menjadi fokus utama dari model project based learning. Mulanya dikembangkan oleh guru, atau jika waktu memungkinkan, tim mahasiswa dapat digunakan untuk mengembangkan pertanyaan ini sebagai bagian dari proyek itu sendiri.

c) Student choice and student voice maksudnya pilihan siswa dan komentar siswa sangat penting bagi partisipasi mahasiswa aktif terhadap kepemilikan proyek. komentar mahasiswa dan pilihannya sangat penting bagi project based learning. Guru 
harus memberi kesempatan bagi siswa untuk memilih dalam pembelajaran project based learning.

d) Specific processes for investigation and research maksudnya banyak aktivitas instruksional yang muncul secara alami dalam proyek itu sendiri. Selain prosedur instruksional, siswa harus menyelesaikan pula kegiatan tersebut, beberapa guru mungkin ingin menggunakan pembelajaran kecil dalam konteks project based learning untuk menyajikan informasi bagi siswa di seluruh kelas agar semua kelompok memahami perintah secara spesifik dan dapat menyelesaikan proyek mereka.

e) Student inquiry and innovation maksudnya memberikan penekanan pada siswa agar terlibat dalam masalah dan menemukan proyek-proyek yang berguna. Siswa bekerja secara bersama untuk melakukan proses penemuan dan inovasi dari lembar kerja yang disediakan untuk berbuat dalam konteks yang nyata atau sistem tugas. f) Opportunities for reflection maksudnya melalui kolaborasi dan kerja kelompok, siswa mempunyai kesempatan untuk memecahkan masalah sebagai salah satu kegiatan pengembangan keterampilan. Siswa dalam kelompok saling berdiskusi dalam menyelesaikan masalah.

g) Feedback and revision maksudnya umpan balik dilakukan untuk mengetahui apa yang telah dicapai, apa yang sudah selesai dan apa yang belum selesai dilakukan.

h) Public presentation of the project results maksudnya ada presentasi atau publikasi dari hasil proyek yang telah dikerjakan.

Kedua versi tersebut adalah menurut kurikulum 2013 dan menurut Bender. Kurikulum 2013 menggambarkan langkah-langkah Model project based learning sebagai berikut: merencanakan aktivitas belajar, penentuan pertanyaan mendasar, menyusun topik pembahasan, menyusun perencanaan, menyusun jadwal, monitoring, menguji hasil, evaluasi pengalaman, dan memberikan 
reward. Dengan desain sebagai berikut:

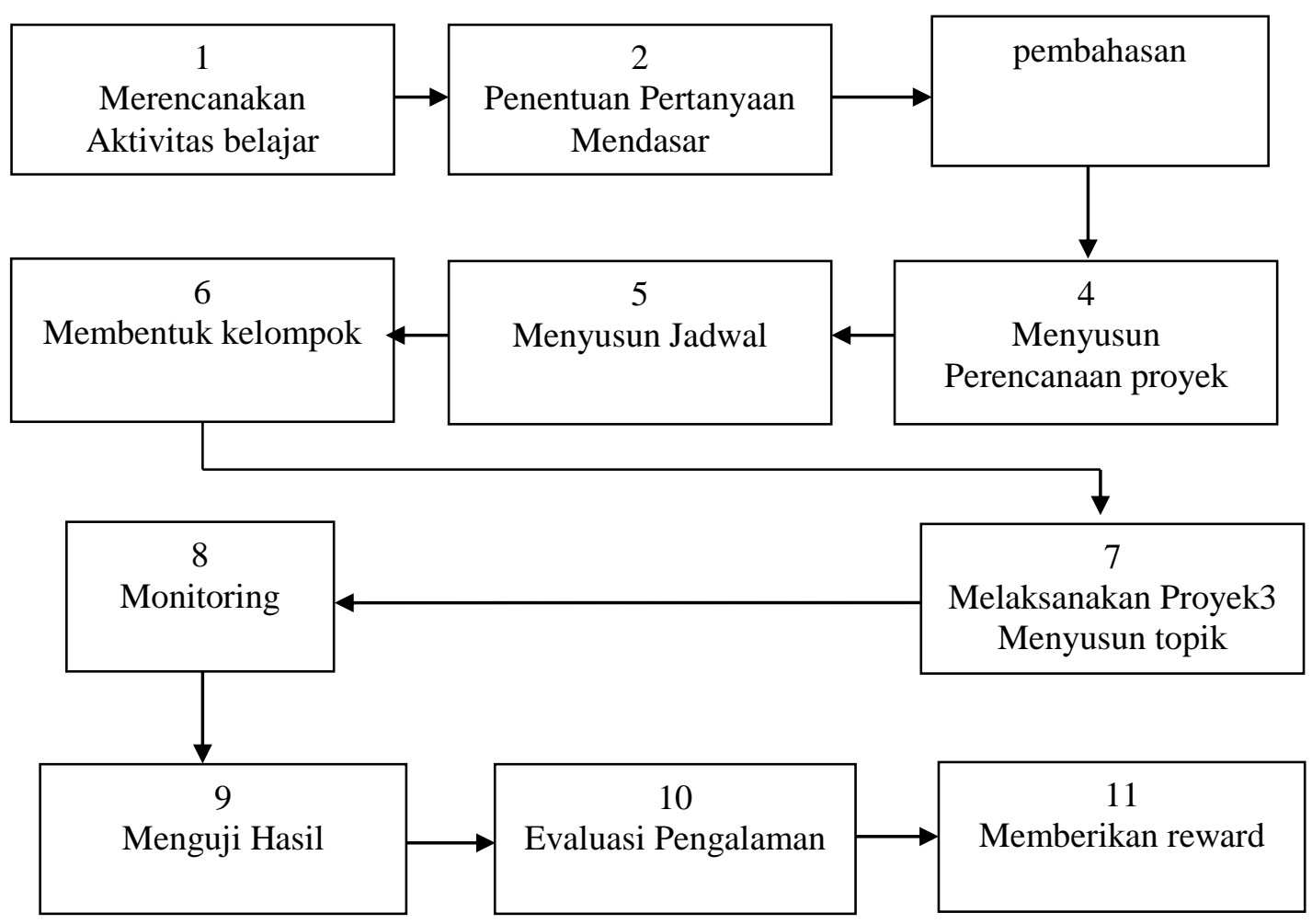

Gambar 3. Langkah Pengembangan Model Project Based Learning

Model project based

learning yang dikembangkan dalam penelitian disesuaikan dengan anak berkebutuhan khusus yang diobservasi. Adapun penjelasan langkah model project based learning adalah:

a. Merencanakan aktivitas belajar, merupakan langkah pertama yang dilakukan oleh guru dengan siswa sebelum menggunakan model project based learning, termasuk materi yang akan diajarkan dan cara menyusun proyek berdasarkan materi yang akan diajarkan.

b. Menentukan

pertanyaan mendasar. Ini merupakan langkah kedua, guru memberikan pertanyaan-pertanyaan untuk mengaitkan materi yang sudah dan akan dipelajari oleh siswa. Pertanyaan mendasar ini, dapat dimulai dengan pernyataanpernyataan dan penjelasanpenjelasan tentang materi sebelumnya. 
c. Menyusun topik pembahasan. Ini merupakan langkah ketiga, guru menyusun topik pembahasan yang akan dibahas dalam beberapa kali pertemua, dengan mangurutkan materi yang akan diajarkan dimulai dari mengenal bentuk bangun datar, contohcontoh benda datar, hingga merancang bentuk dari benda yang memiliki volume ke dalam bentuk tangram. Kegiatan membentuk tangram harus diurutkan dalam penyampaiannya agar siswa mampu secara mandiri membuat tangram.

d. Menyusun perencanaan proyek. Ini merupakan langkah keempat yang dilakukan, guru menyusun rencana proyek yang dapat dibuat oleh siswa dalam pembelajaran. Penyusunan ini juga perlu didukung dengan penyediaan media untuk memudahkan siswa dalam siswa dalam menyelesaika proyek mereka nanti.

e. Menyusun jadwal. Ini merupakan langkah kelima, guru menyusun jadwal proyek yang akan dilaksanakan, ada beberapa proyek yang dilaksanakan yaitu pembuatan tangram dari berbagai bentuk bangun datar, membuat tangram dengan menggunakan kertas lipat, dan menggunakan stick es krim.

f. Membentuk kelompok, ini merupakan langkah keenam, guru membentuk siswa menjadi beberapa kelompok, setiap kelompok terdiri dari 4 orang siswa dengan kemampuan yang heterogen.

g. Melakukan proyek. Ini merupakan langkah ketujuah, guru meminta siswa membuat proyek pertama yaitu pembuatan tangram dari berbagai bentuk bangun datar, dan secara berkelompok siswa membentuk tangram dari berbagai bentuk bangun datar. Selanjutnya untuk proyek kedua, siswa membuat proyek tangram dari kertas lipat yang digunting dan dibentuk sendiri. Kemudian proyek yang ketiga, siswa membuat tangram dari stik es krim.

h. Monitoring. Ini merupakan langkah kedelapan, guru melakukan monitoring, memantau hasil kerja siswa secara bergiliri dengan cara 
mengunjungi kelompok

kelompok.

i. Melakukan uji hasil. Ini merupakan langkah ke sembilan, guru menguji hasil dengan cara meminta siswa melakukan presentasi dari hasil pembuatan proyek. Presentasi ini, menjadi bagian penting yang dilakukan untuk memperkenalkan berbagai bentuk tangram yang dibuat oleh siswa.

j. Evaluasi pengalaman. Ini merupakan langkah ke sepuluh, guru mengevaluasi pengalaman siswa, dengan melakukan tanya jawab tentang perasaan siswa dan kegiatan yang dilakukan selama pembuatan proyek.

k. Memberikan reward, ini merupakan langkah ke sebelas, guru memberikan reward berupa pujian kepada semua siswa yang telah bekerja dalam proyek pembuatan tangram. Namun, pada dasarnya reward berupa pujian dilakukan pada setiap akhir kelompok memprensentasikan hasil kerja di depan kelas.

Adapun hasil validasi dari ahli pengembangan model dapat dilihat pada tabel di bawah ini.

Tabel 3. Skor Penilaian Ahli Pengembangan ditinjau dari Aspek Kelayakan model project based learning

\begin{tabular}{clc}
\hline No. & \multicolumn{1}{c}{ Indikator Penilaian } & Skor \\
\hline 1. & $\begin{array}{l}\text { Kesesuaian model project based learning yang } \\
\text { dilakukan dengan proses pembelahasil studi kasus }\end{array}$ & 5 \\
2. & $\begin{array}{l}\text { Ketepatan pengembangan model project based } \\
\text { learning yang disajikan }\end{array}$ & 5 \\
3. & $\begin{array}{l}\text { Pengembangan model project based learning dapat } \\
\text { membuat siswa aktif dalam belajar }\end{array}$ & 5 \\
4. & $\begin{array}{l}\text { Pengembangan model project based learning } \\
\text { dijelaskan dengan mengaicu pada kurikulum 2013 }\end{array}$ & 5 \\
5. & $\begin{array}{l}\text { Pengembangan model project based learning } \\
\text { merujuk pada metode pembelajaran kreatif, aktif, } \\
\text { dan menyenangkan } \\
\text { Skor Total }\end{array}$ & 5 \\
& $\quad$ Rata-rata Skor & $\mathbf{2 5}$ \\
& Kategori & Sangat Baik \\
\hline
\end{tabular}


Skala penilaian kualitas model project based learning oleh ahli pengembangan model diperoleh dari konversi data kuantitatif skala 5 yang tercantum dalam Tabel 3 . Validasi produk yang dikembangkan, oleh ahli materi tidak hanya skor penilaian skala
5 yang dikonversikan tetapi juga tanggapan, komentar, dan saran dari ahli pengembangan model tersebut untuk menjadi pedoman perbaikan produk. Saran Perbaikan dari ahli pengembangan model untuk diterapkan di sekolah inklusi.

Tabel 4. Saran Perbaikan Ahli Model Project Based Learning dan Revisi

\begin{tabular}{|c|c|c|}
\hline No. & Saran Perbaikan Ahli Model & Revisi \\
\hline 1. & $\begin{array}{l}\text { Perlu perencanaan untuk memulai } \\
\text { pembelajaran }\end{array}$ & $\begin{array}{l}\text { Memulai langkah model project based } \\
\text { learning dengan merencanakan } \\
\text { aktivitas }\end{array}$ \\
\hline 2. & $\begin{array}{l}\text { Harus ada pertanyaan yang } \\
\text { mendasari pelaksanaan projek yang } \\
\text { akan diadakan, sehingga siswa bisa } \\
\text { bekerja dengan mengacu pada } \\
\text { jawaban pertanyaan. }\end{array}$ & $\begin{array}{l}\text { Langkah kedua dengan guru } \\
\text { mengajukan pertanyaan mendasar } \\
\text { pada siswa. }\end{array}$ \\
\hline 3. & $\begin{array}{l}\text { Pertanyaan mendasar perlu diikuti } \\
\text { dengan perencanaan aktivitas, } \\
\text { untuk mengarahkan proses } \\
\text { pembelajaran yang dilaksanakan }\end{array}$ & $\begin{array}{l}\text { Langkah ketiga guru membuat } \\
\text { perencanaan aktivitas belajar. }\end{array}$ \\
\hline 4. & $\begin{array}{l}\text { Sebaiknya pelaksanaan proyek, } \\
\text { siswa dibuat kooperatif namun } \\
\text { mereka tetap bekerja sendiri }\end{array}$ & $\begin{array}{l}\text { Langkah model didesain dengan } \\
\text { kooperatif model, siswa dibentuk } \\
\text { dalam kelompok untuk menyelesaikan } \\
\text { proyek }\end{array}$ \\
\hline 5. & $\begin{array}{l}\text { Tidak cukup diakhiri dengan hasil } \\
\text { karya, masih harus ada reward }\end{array}$ & $\begin{array}{l}\text { Memasukkan penghargaan berupa } \\
\text { reward dalam langkah-langkah model } \\
\text { project based learning. }\end{array}$ \\
\hline
\end{tabular}

Validasi ahli hasil validasi ahli pembelajaran pengembangan model project terhadap produk yang based learning terhadap dikembangkan dapat dilihat kalayakan model di sekolah pada tabel 5. inklusi telah dilaksanakan. Data 
Tabel 5. Skor Penilaian Ahli Pembelajaran ditinjau dari Aspek langkahlangkah Pembelajaran

\begin{tabular}{clc}
\hline No. & \multicolumn{1}{c}{ Indikator Penilaian Aspek Penyajian Pembelajaran } & Skor \\
\hline 1. & $\begin{array}{l}\text { Prosedur pengembangan model mengakomodasi keberagaman anak di } \\
\text { sekolah inklusi. }\end{array}$ & 4 \\
2. & Langkah pembelajaran membuat siswa aktif & 4 \\
3. & Waktu belajar menjadi lebih efektif & 5 \\
4. & Siswa bekerja aktif dalam kelompok & 5 \\
5. & Kegiatan belajar menjadikan siswa berkreasi dengan ide-ide baru & 4 \\
6. & Ketekunan dan ketelitian dalam mengerjakan proyek & 4 \\
& Skor Total & 26 \\
& Rata-rata Skor & 4,3 \\
& Kategori & Baik \\
\hline
\end{tabular}

Data hasil validasi dan

Saran Perbaikan dari ahli pembelajaran terhadap pengembangan model project

based learning, dapat dilihat

pada tabel 6 berikut.

Tabel 6. Saran Perbaikan Ahli Pembelajaran dan Revisi

\begin{tabular}{lll}
\hline No. & \multicolumn{1}{c}{$\begin{array}{c}\text { Saran Perbaikan Ahli } \\
\text { Pembelajaran }\end{array}$} & \multicolumn{1}{c}{ Revisi } \\
\hline 1. & $\begin{array}{l}\text { Perlunya mengubah prosedur } \\
\text { pengembangan model yang } \\
\text { dapat mengakomodasi } \\
\text { keberagaman kemampuan anak } \\
\text { di sekolah inklusi. }\end{array}$ & $\begin{array}{l}\text { Mengubah prosedur pengembangan model yang } \\
\text { dapat mengakomodasi keberagaman kemampuan } \\
\text { anak di sekolah inklusi. }\end{array}$ \\
\end{tabular}

2. Setiap langkah pembelajaran Membuat langkah pembelajaran yang mengaktifkan harus membuat siswa keseluruhan siswa berpartisipasi secara keseluruhan

3. Upayakan penggunaan waktu Memperbaiki langkah, berdiskusi dengan guru, belajar menjadi lebih efektif sehingga waktu belajar efektif diperoleh. dalam membahas setiap topik materi

4. Langkah pembelajaran mengupayakan siswa perlu bekerja aktif dalam kelompok

Memperbaiki Langkah pembelajaran siswa aktif dalam kelompok

5. Perlunya mengembangkan Mengembangkan kegiatan belajar siswa untuk kegiatan belajar, sehingga siswa dapat berkreasi dengan ide-ide baru berkreasi dengan ide-ide baru

$\begin{array}{ccl}\text { Respon peserta } & \text { didik } & \text { based learning diketahui melalui } \\ \text { dalam pembelajaran } & \text { dengan } & \text { angket. Angket ini terdiri dari dua } \\ \text { menggunakan model } & \text { project } & \text { jenis, yaitu angket motivasi dan }\end{array}$


aktivitas belajar siswa. Data hasil motivasi belajar siswa dapat dilihat pada tabel berikut:

Tabel 7. Data Hasil Motivasi Belajar Siswa

\begin{tabular}{lcc}
\multicolumn{1}{c}{$\mathrm{B}$} & \\
\hline \multicolumn{1}{c}{ Kategori } & Motivasi & Aktivitas \\
\hline Kurang & 0 & 0 \\
Gukup & 7 & 0 \\
Baik & 13 & 9 \\
Šangat Baik & 10 & 21 \\
JUMLAH & \multicolumn{3}{c}{$\mathbf{3 0}$} \\
\hline
\end{tabular}

sarkan tabel sebanyak 30 siswa menunjukkan bahwa motivasi belajar siswa sebanyak 7 orang berada kategori cukup termotivasi, 13 siswa berada pada kategori motivasi yang baik, dan 10 orang siswa berada pada kategori sangat baik. Hal ini menunjukkan bahwa motivasi anak dalam belajar dengan menggunakan model project based learning cocok untuk diterapkan di sekolah. Adapun aktivitas belajar siswa sebanyak 9 siswa berada pada kategori baik, dan 21 orang siswa berada pada kategori sangat baik. Hal ini menunjukkan bahwa aktivitas anak dalam belajar dengan menggunakan model project based learning cocok untuk diterapkan di sekolah.

Pengembangan ... (Nur Hidayah)

\section{Kesimpulan}

Jadi, model project based learning telah selesai dikembangkan. Tahapan-tahapan menganalisis kebutuhan, mendesain pengembangan, memproduksi/ mengembangkan model, melakukan evaluasi produk, dan melakukan uji coba produk akhir pengembangan telah dilakukan yaitu kajian produk akhir pengembangan model project based learning merupakan hasil konfirmasi antara teori dan praktik di lapangan. Kajian pengembangan model project based learning merujuk pada literatur yang berisi konsep yang dapat dipertanggungjawabkan.

Langkah-langkah yang paling efektif dalam mengembangkan model project based adalah menganalisis kebutuhan, mendesain pengembangan, memproduksi/ mengembangkan model project based learning, melakukan evaluasi pengembangan, dan melakukan uji coba lapangan; dan kualitas pengembangan model project based learning yang dikembangkan menurut penilaian ahli materi termasuk kriteria "sangat baik" dengan rerata skor 4,8, menurut ahli pembelajaran termasuk kriteria "baik" dengan rerata skor 4,3.

Penilaian pengembangan model project based learning menunjukkan hasil yang positif. Hasil penilaian ahli model pembelajaran dan ahli AdMathEdu | Vol.7 No.2 | Desember 2017 
pembelajaran hasil pengembangan termasuk dalam kategori "baik". Hasil penilaian menunjukkan bahwa model project based learning memiliki kemudahan penggunaannya dalam pembelajaran. Pengembangan model project based learning diperoleh setelah melakukan uji coba lapangan. Pengembangan model project based learning telah melalui proses penilaian kualitas oleh ahli pengembangan pembelajaran dan ahli pembelajaran, selanjutnya direvisi sesuai saran. Produk hasil revisi tersebut diujicobakan di lapangan. Berdasarkan rerata skor yang diperoleh dari data respon siswa menghasilkan rerata skor lebih dari 4, sehingga dapat dinyatakan bahwa sebagian besar siswa sebagai subjek uji coba lapangan sangat setuju dengan penerapan model project based learning yang dikembangkan peneliti untuk dapat digunakan di sekolah yang lain.

\section{Pustaka}

Borg, W.R., Gall, M.D., \& Gall, J.P. 2007. Educational Research $\left(8^{\text {th }}\right.$ ed.). Arlington Street, Boston, MA: Pearson Education.

Borich, G.D. (2007). Effective teaching methods: research-based practice (6 $6^{\text {th }}$ ed.). Upper Saddle River, NJ: Pearson Education.

Depdiknas. 2008. Pedoman Pelaksanaan Materi Pembelajaran dan
Pengembangan Pembelajaran

Contextual (CTL) Sekolah

Menengah Pertama (SMP).

Jakarta: BP Cipta Jaya.

Hârtescu, I. 2014. Providing technology support for project-based learning. The International Scientific Conference eLearning and Software for Education 3: 223-229. Bucharest: "Carol I" National Defence University. Diambil pada tanggal 14 Juli 2014 pukul 14.32 WIB dari http://search.proquest.com/docvie w/1534145093? accountid=31324

Kidd, W. \& Czerniawski, G. 2010. Succesful Teaching 14-19 Theory Practice and Reflection. New Delhi, India: Sage Publication.

Joyce, B., Calhoun, E., \& Hopkins, D. (2009). Models of learning tools for teaching ( $3^{\text {rd }}$ ed.). Two Penn Plaza, NY: Mc Graw Hill.

Muresan, M. 2014. Project based collaborative learning for adult education. The International Scientific Conference eLearning and Software for Education 3: 303-309. Bucharest: "Carol I" National Defence University. Diambil pada tanggal 26 Agustus 2014 pukul 15.13 WIB dari http://search.proquest.com/docvie w/?accountid $=31324$.

Matutina, J. A. 2014. Pengembangan Lembar Kerja Siswa Mata Pelajaran Matematika Materi Bentuk Aljabar Dengan Pendekatan Kontekstual Untuk Siswa SMP Kelas VII. Skripsi. Yogyakarta: Fakultas MIPA, Universitas Negeri Yogyakarta.

Pickens, B.C. et. al 2012. Project based learning: enriching counselor 
education through real world learning. APA style reference information. Article 15 (Halaman 3, volume 1). Diambil pada tanggal 12 Juli 2014 pukul 12.27 WIB dari http://www.counseling.org/library I

Santrock, J.W. 2009. Psikologi pendidikan (Edisi 3 buku 1). (Terjemahan Diana Angelica). Avenue of the Americas, NY: McGraw-Hill. (Buku asli diterbitkan tahun 2008)

Sardiman. 2011. Interaksi \& motivasi belajar mengajar. Jakarta: Raja Grafindo Persada.

Schunk, D.H. 2012. Learning theories an educational perspective. (Terjemahan Eva Hamdiah \& Rahmat Fajar). Upper Saddle River, NJ: Pearson Education. (Buku asli diterbitkan tahun 2008)

The National Council of Teacher of Mathematics, Inc. 2000. Principles and Standards for School Mathematics. Association Drive, Reston, VA: Library of Congres Cataloguing-inPublication Data.

Uno, H. B. 2012. Teori motivasi dan pengukurannya. Jakarta Bumi Aksara.

Widiyoko, eko Putro. 2009. Evaluasi Program Pembelajaran Panduan Praktis Bagi Pendidik dan Calon Pendidik. Yogyakarta: Pustaka Pelajar.

Penyusunan Instrumen Penelitian.

Yogyakarta: Pustaka Pelajar. 